\title{
Aerenchyma development in different root zones of maize genotypes under water limitation and different phosphorus nutrition
}

\author{
A.S. DÍAZ ${ }^{1}$, G.M. AGUIAR ${ }^{1}$, M.P. PEREIRA ${ }^{1}$, E. MAURO de CASTRO ${ }^{1}$, P.C. MAGALHÃES ${ }^{2}$, \\ and F.J. PEREIRA ${ }^{3 *}$. \\ Universidade Federal de Lavras, Departamento de Biologia, 37200-000, Lavras, Minas Gerais, Brazil ${ }^{1}$ \\ Centro Nacional de Pesquisa de Milho e Sorgo, 35701-970 Sete Lagoas, Minas Gerais, Brazil ${ }^{2}$ \\ Universidade Federal de Alfenas, Instituto de Ciências da Natureza, 372130-001, Alfenas, Minas Gerais, Brazil
}

\begin{abstract}
Root cortical aerenchyma (RCA) is suggested to reduce metabolic cost for root growth, but it might lower water uptake by plants. The objective of this work was to evaluate the effects of drought and phosphorus on the RCA development along the root axis and to elucidate its role in water stress tolerance of two maize genotypes. Plants of drought-tolerant DKB390 and drought-sensitive BRS1010 genotypes were grown in Vermiculite at field capacity of 100, 75, 50, and $25 \%$ and supplied with $0.1,0.4$, and $0.8 \mathrm{mM}$ phosphorus. Growth parameters, RCA, and plant P content were evaluated for all plants. Higher RCA development was observed in DKB390 than in BRS1010. Drought reduced the percentage of RCA in the root-hair zone of both genotypes but increased its development in the root maturation zone. Phosphorus limitation enhanced RCA development only in the DKB390. Under drought stress, DKB390 showed resilient growth whereas growth was inhibited in BRS1010. Higher root P content was related to its higher supply. Therefore, RCA formation was induced either by drought or by phosphorus limitation, while no interaction was evident. The RCA development varied along the root axis in order to balance water and phosphorus uptake and the drought response was genotype dependent.
\end{abstract}

Additional key words: biomass allocation, drought tolerance, relative growth rate, root development.

\section{Introduction}

The development of root cortical aerenchyma (RCA) is considered a key trait in improving drought tolerance in maize (Postma and Lynch 2011, Jaramillo et al. 2013, Souza et al. 2013, Chimungu et al. 2015). In fact, this tissue may reduce the metabolic cost for exploring the soil for nutrients and enhancing water uptake (Jaramillo et al. 2013, Lynch 2015). Exploration of soil depends on the root growth and development (Jaramillo et al. 2013). Root growth and development are related to biomass allocation to roots as they become a strong metabolic sink for photoassimilates; and these metabolites are used to aid the production of new cells and to maintain the existing ones (Jaramillo et al. 2013, Lynch 2015). Therefore, development of the aerenchyma reduces the total number of cells and their metabolic cost whereas it allocates more photoassimilates to the meristems and so enhances growth. Radial water transport in roots occurs in the apoplastic and symplastic pathways. As a consequence of RCA formation, large intercellular spaces develop in the root cortex, reducing the capacity of both pathways. This change elicits different responses in plants under drought conditions. However, several studies show that enhanced drought tolerance is attributed to RCA development (Postma and Lynch 2011, Jaramillo et al. 2013, Souza et al. 2013), even if a limited water and nutrient uptake is found in plants with higher RCA content under drought conditions (Lynch 2007, Yang et al. 2012, Valdez 2014). As water uptake is lower in distal parts of the roots (Gambetta et al. 2013), we suggest that these divergent results are related to modified strategies, particularly along the longitudinal root axis to balance water uptake and aerenchyma development.

Submitted 2 October 2016, last revision 11 November 2017, accepted 14 November 2017.

Abbreviations: CT - cortex thickness; DV - the diameter of the metaxylem vessels; ED - endodermis thickness; EP - epidermis thickness, RCA - root cortical aerenchyma; X and P - xylem and phloem percentage in the vascular cylinder, respectively.

Acknowledgements: The authors thank the National Council of Technological and Scientific Development, the Coordination for the Improvement of Higher Education, the Minas Gerais State Research Foundation, and the National Council of Science and Technology, Mexico for funding the research.

* Corresponding author: fabricio.pereira@unifal-mg.edu.br 
The development of RCA in maize is induced by different environmental factors such as flooding (Pereira et al. 2008), drought (Souza et al. 2013), and phosphorus limitation (Coelho et al. 2006). The root cortical aerenchyma in maize is lysigenous and related to programmed cell death (Lenochová et al. 2009). In addition, its development is ethylene-dependent (Pires et al. 2015). However, the mechanisms of aerenchyma formation in maize are described only considering some environmental factors individually and the effects of combination of these factors remain unclear.

Drought is a key factor limiting global plant production. Drought also reduces phosphorus availability to plants (He and Dijkstra 2014), and under tropical conditions, the phosphorus content in soils may be very low (Souza et al. 2013). In this study, we hypothesize that: 1) there are effects of drought alone and phosphorus alone as well as an effect of combination of both factors on RCA formation, 2) RCA formation varies along the root axis, and 3) the responses of RCA development to drought or phosphorus limitation are genotypedependent. Therefore, the objective of this work was to evaluate the effects of phosphorus and drought on RCA development along the root axis and its role in water stress tolerance in two maize genotypes.

\section{Materials and methods}

Plants and experimental design: The experiments were carried out in a greenhouse at the Biology Department of the Federal University of Lavras, Lavras, Minas Gerais, Brazil (21 $\left.14^{\prime} 43^{\prime \prime} \mathrm{S}, 45^{\circ} 59^{\prime} 59^{\prime \prime} \mathrm{W}\right)$. Two maize (Zea may L.) genotypes were used in these experiments: DKB390 reported as drought-tolerant (Souza et al. 2013) and BRS1010 described as drought-sensitive (Magalhães et al. 2015). Seeds obtained from the National Maize and Sorghum Research Center, Sete Lagoas, Minas Gerais, Brazil were sown in plastic trays containing $4000 \mathrm{~cm}^{3}$ of Vermiculite irrigated to field capacity and grown in a chamber maintained at room temperature and constant irradiance of $84 \mu \mathrm{mol} \mathrm{m} \mathrm{m}^{-2} \mathrm{~s}^{-1}$. The vermiculite field capacity (FC) was determined as the maximum amount of water held by $1 \mathrm{dm}^{3}$ of Vermiculite upon saturation.

Experiments were carried out separately for each genotype (DKB390 or BRS1010) to minimize variability owing to their growth differences (Souza et al. 2013, Magalhães et al. 2015). Plants (about $10 \mathrm{~cm}$ in height) were transferred to plastic trays containing $3000 \mathrm{~cm}^{3}$ of Vermiculite and diluted nutrient solution (Hoagland and Arnon 1950) to $40 \%$. The volume of nutrient solution added to vermiculite was adjusted so as to obtain four water conditions: $100,75,50$, and $25 \%$ of the FC. In addition, the phosphorus content was modified by changing the concentration of $\left(\mathrm{NH}_{4}\right)_{3} \mathrm{PO}_{4}$ in the nutrient solution. The $\mathrm{P}$ concentrations were $0.1,0.4$, and $0.8 \mathrm{mM}$ where $0.4 \mathrm{mM}$ is the recommended concentration by Santos et al. (2015). The experimental design was completely randomized in a factorial $4 \times 3$ scheme with three replicates. Each replicate comprised one plant. The experiment was carried out for $30 \mathrm{~d}$ under these conditions. Water lost due to evapotranspiration and nutrient solution were replenished daily and weekly, respectively. Water loss was determined by monitoring the difference in the weight of each tray daily.

Growth analysis: At the end of the experimental period, plants were sampled and separated into leaves, roots, and culms. Fresh leaves were scanned to obtain images which were used for the leaf area determination using the UTHSCSA-Imagetool software. Subsequently, the leaves, roots, and culms were oven-dried at $60{ }^{\circ} \mathrm{C}$ to constant mass and weighed using an analytical scale (AY220, Shimadzu, Kyoto, Japan). The relative growth rate (RGR) and the leaf area ratio (LAR) were calculated according to Hunt et al. (2002). Biomass partitioning was calculated for each organ by dividing its dry mass by the total plant dry mass, and the results were expressed as a percentage (Santos et al. 2015).

Phosphorus analysis: The $\mathrm{P}$ content in plants was measured using $500 \mathrm{mg}$ of dried tissue, which was triturated and digested in $10 \mathrm{~cm}^{3}$ of $\mathrm{HNO}_{3}$ at $150{ }^{\circ} \mathrm{C}$ for $30 \mathrm{~min}$ in a block digestion system. Subsequently, $1 \mathrm{~cm}^{3}$ of $\mathrm{HClO}_{4}$ was added and the temperature was increased to $210{ }^{\circ} \mathrm{C}$ for $20 \mathrm{~min}$. The digested material was diluted to $25 \mathrm{~cm}^{3}$ with distilled water (Sarruge and Haag 1974), and the $\mathrm{P}$ concentration was determined with an atomic absorption spectrometer (AAnalyst 800, Perkin Elmer, Waltham, USA).

Root cortical aerenchyma analysis: Roots were sampled by carefully removing the vermiculite and then fixed in FAA $[70 \%(\mathrm{v} / \mathrm{v})$ formaldehyde + concentrated acetic acid $+70 \%(\mathrm{v} / \mathrm{v})$ ethanol, 0.5:0.5:9.0 (v/v/v)] for $72 \mathrm{~h}$ (Johansen 1940) and then stored in $70 \%$ ethanol until further analysis. The roots sectioning was performed at the root-hair zone and maturation zone with a benchtop microtome. Two different root zones were evaluated because root parts showed different water uptake and morphological traits. Sections were cleared with $50 \%$ $(\mathrm{m} / \mathrm{v})$ sodium hypochlorite, rinsed twice in distilled water for $10 \mathrm{~min}$, stained with safra-blue solution $[1 \%(\mathrm{~m} / \mathrm{v})$ safranin and $0.1 \%(\mathrm{~m} / \mathrm{v})$ astra blue in a $7: 3$ ratio] and mounted on slides with $50 \%(\mathrm{v} / \mathrm{v})$ glycerol. Slides were photographed using an Olympus $C X 31$ light microscope (Olympus, Tokyo, Japan) and image analysis was performed with the ImageTool v. 3.0 software (University of Texas Health Science Center, San Antonio, USA). We measured the percentage of aerenchyma intercellular spaces in root cortex (AE\%). Other anatomical data are available in Tables 1 and 2 Suppl. 
Statistical analysis: Three fields on one slide per replicate were evaluated and data were averaged to each replicate. The statistical analyses were performed using the Sisvar 5.3 software (Ferreira 2011). The Shapiro-Wilk test was used to test whether the data had a normal

\section{Results}

No interaction between water treatments and phosphorus concentrations was observed for the variables evaluated $(P>0.05)$. Therefore, results are shown separately for each factor.
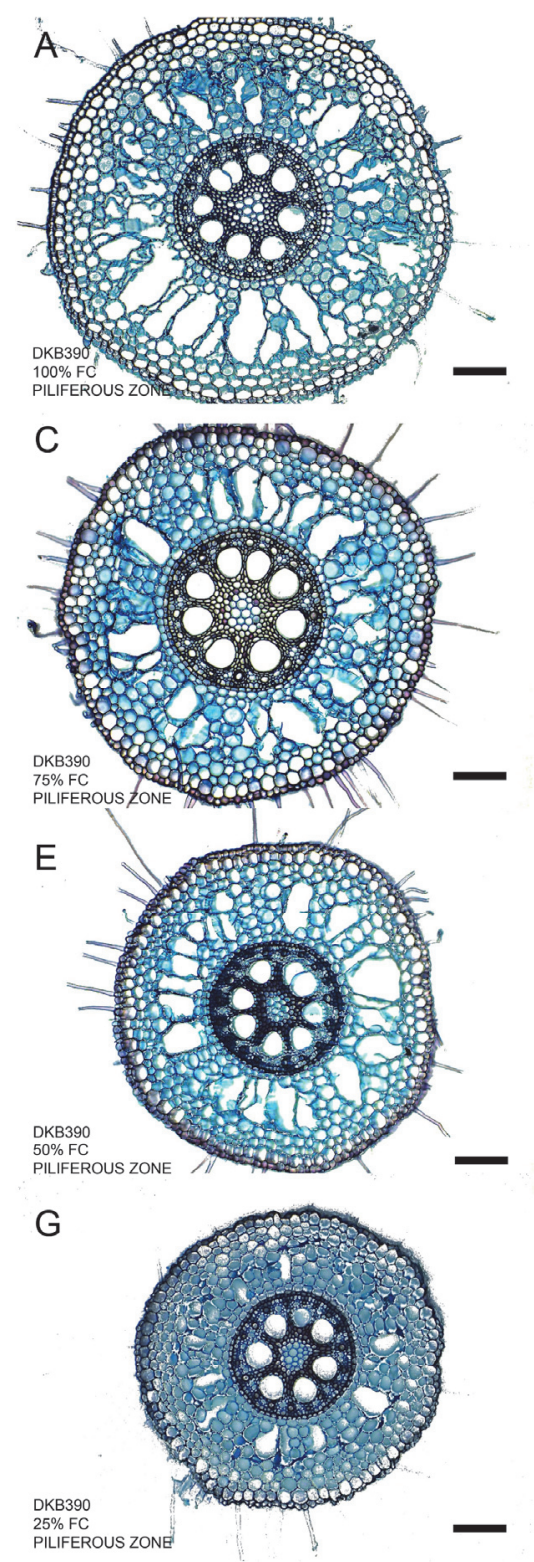

distribution. Subsequently, data were subjected to twoway $A N O V A$. Statistical significance was tested at $P<0.05$ and the Scott-Knott test was used to compare the mean values.

The relative growth rate was reduced under all drought treatments for sensitive genotype BRS1010; however, for tolerant genotype DKB390, only the treatments with $\mathrm{FC}$ of 50 and 25 reduced this variable
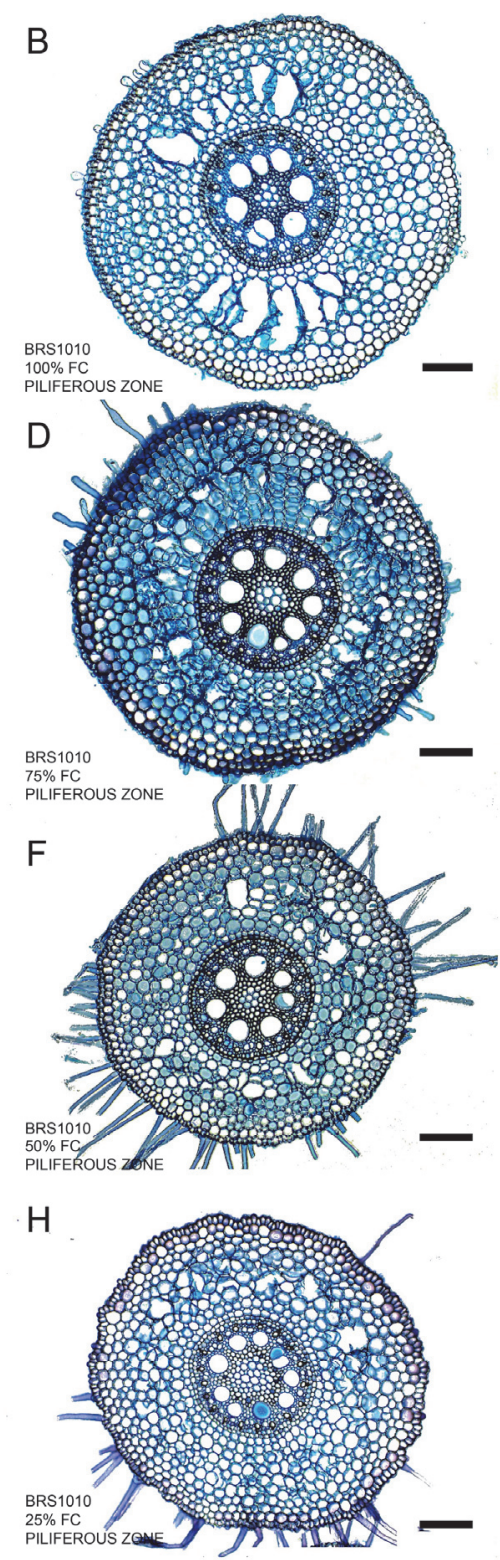

Fig. 1. Root sections in the root-hair zone of two maize genotypes DKB390 (drought-tolerant; $A, C, E, G$ ) and BRS1010 (droughtsensitive; $B, D, F, H)$ under different water treatments. Field capacity $100 \%(A, B), 75 \%(C, D), 50 \%(E, F)$, and $25 \%(G, H)$ Bars $=100 \mu \mathrm{m}$. 
Table 1. Relative growth rate (RGR) $\left[\mathrm{mg} \mathrm{mg}^{-1} \mathrm{day}^{-1}\right]$ and biomass allocation $\left[\mathrm{g} \mathrm{kg}^{-1}\right.$ (plant d.m.)] to leaves, culm, and roots of the DKB390 (drought-tolerant) and BRS1010 (drought-sensitive) maize plants under different water treatments. Means \pm SDs, $n=36$, means followed by different letters in columns differ at $P<0.05$ according to Scott-Knott test.

\begin{tabular}{|c|c|c|c|c|c|c|c|c|}
\hline $\begin{array}{l}\text { Field } \\
\text { capacity[\%] }\end{array}$ & $\begin{array}{l}\text { RGR } \\
\text { DKB390 }\end{array}$ & BRS1010 & $\begin{array}{l}\text { Leaves } \\
\text { DKB390 }\end{array}$ & BRS1010 & $\begin{array}{l}\text { Culm } \\
\text { DKB390 }\end{array}$ & BRS1010 & $\begin{array}{l}\text { Roots } \\
\text { DKB390 }\end{array}$ & BRS1010 \\
\hline 100 & $52.00 \pm 7.2^{\mathrm{a}}$ & $39.74 \pm 6.3^{\mathrm{a}}$ & $323.9 \pm 57^{\mathrm{a}}$ & $271.6 \pm 52^{\mathrm{a}}$ & $178.3 \pm 42^{\mathrm{a}}$ & $140.9 \pm 38^{\mathrm{a}}$ & $497.6 \pm 71^{b}$ & $587.5 \pm 77^{\mathrm{a}}$ \\
\hline 75 & $41.08 \pm 6.4^{\mathrm{a}}$ & $25.28 \pm 5.0^{\mathrm{b}}$ & $320.4 \pm 57^{\mathrm{a}}$ & $253.7 \pm 50^{\mathrm{a}}$ & $159.6 \pm 40^{\mathrm{a}}$ & $132.9 \pm 36^{\mathrm{a}}$ & $520.0 \pm 72^{\mathrm{b}}$ & $613.4 \pm 78^{\mathrm{a}}$ \\
\hline 50 & $34.82 \pm 5.9^{b}$ & $25.21 \pm 5.0^{\mathrm{b}}$ & $306.8 \pm 55^{\mathrm{a}}$ & $253.1 \pm 50^{\mathrm{a}}$ & $166.7 \pm 41^{\mathrm{a}}$ & $113.0 \pm 34^{\mathrm{b}}$ & $526.5 \pm 73^{\mathrm{b}}$ & $633.9 \pm 80^{\mathrm{a}}$ \\
\hline 25 & $22.36 \pm 4.7^{\mathrm{b}}$ & $06.46 \pm 2.5^{\mathrm{c}}$ & $275.0 \pm 52^{\mathrm{a}}$ & $262.7 \pm 51^{\mathrm{a}}$ & $153.2 \pm 39^{\mathrm{a}}$ & $155.7 \pm 39^{\mathrm{a}}$ & $571.8 \pm 76^{\mathrm{a}}$ & $581.6 \pm 76^{\mathrm{a}}$ \\
\hline
\end{tabular}

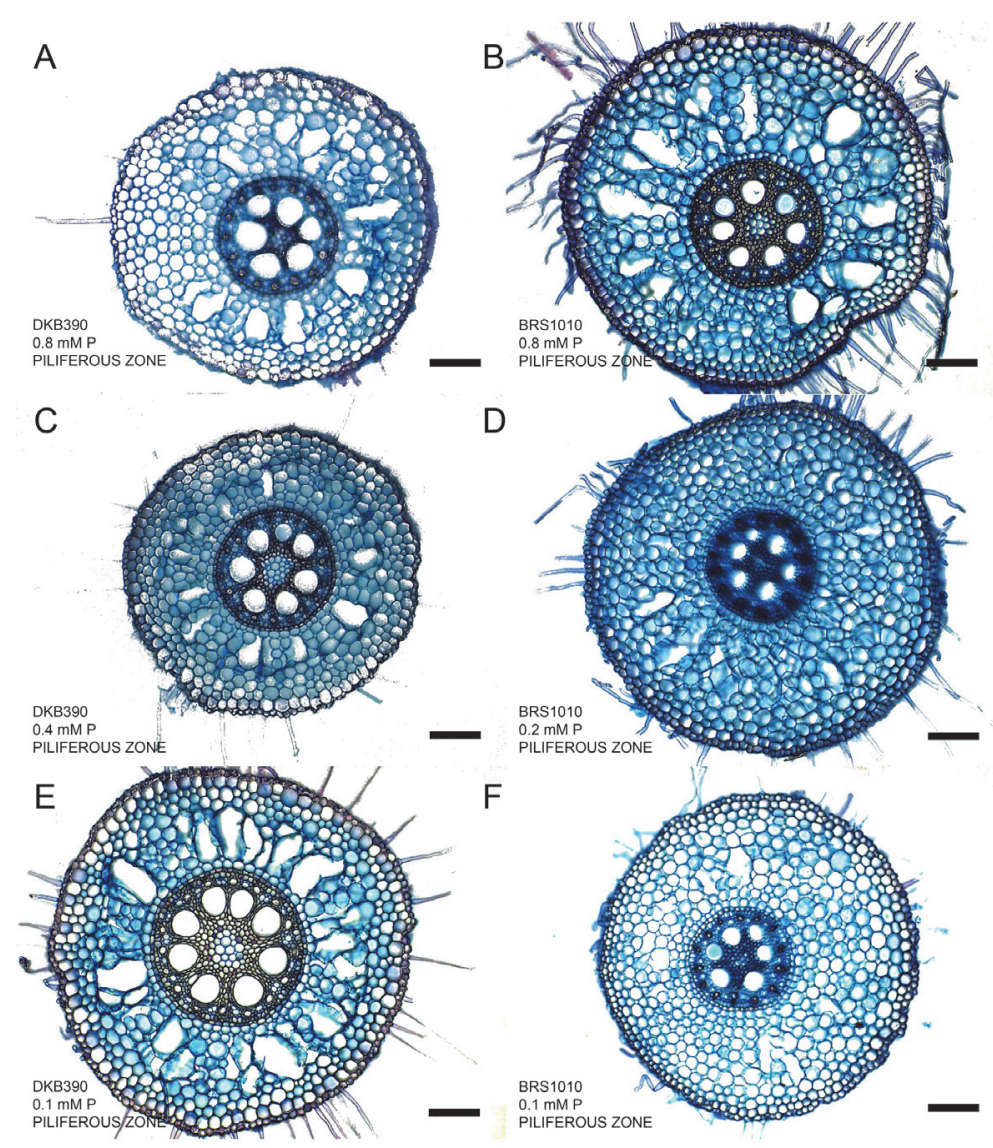

Fig. 2. Root sections in the root-hair zone of two maize genotypes DKB390 (drought-tolerant; $A, C, E$ ) and BRS1010 (droughtsensitive; $B, D, F)$ under different phosphorus concentrations: $0.8 \mathrm{mM}(A, B) 0,4 \mathrm{mM}(C, D)$, and $0.1 \mathrm{mM}(E, F))$. Bars $=100 \mu \mathrm{m}$.

(Table 1). Biomass allocation in leaves and roots was not significantly modified in BRS1010 under drought, whereas the culm biomass allocation was reduced at $50 \%$ FC (Table 1). Increased root development in the DKB390 genotype was observed in plants grown under $25 \% \mathrm{FC}$ (Table 1). Remarkably, for both the maize genotypes, $\mathrm{P}$ supply did not have any significant effect on the growth parameters studied (Table 2).

Phosphorus content was the highest in plants under $25 \%$ of FC for both the genotypes (Table 3). In DKB390, P content remained the same for $\mathrm{FC}$ of 100, 75, or $50 \%$ (Table 3). However, BRS1010 showed lower
$\mathrm{P}$ content when grown at 75 and $50 \%$ FC (Table 3). Furthermore, higher $\mathrm{P}$ concentration in the nutrient solution increased uptake of $\mathrm{P}$ in both the maize genotypes (Table 3).

The overall RCA development was significantly higher in DKB390 genotype (14.53\% of root cortex) than in BRS1010 (11.21\% of root cortex). Reduced RCA formation was observed in the root-hair zone of BRS1010 under all drought treatments (Table 3 and Fig. 1). However, DKB390 showed a reduced aerenchyma formation only at $25 \% \mathrm{FC}$ (Table 3 and Fig. 1). The RCA formation in BRS1010 was not modified by the 
Table 2. Relative growth rate (RGR) $\left[\mathrm{mg} \mathrm{mg}^{-1} \mathrm{day}^{-1}\right]$ and biomass allocation $\left[\mathrm{g} \mathrm{kg}^{-1}\right.$ (plant d.m.)] to leaves, culm, and roots of the DKB390 (drought-tolerant) and BRS1010 (drought-sensitive) maize plants under different phosphorus supply Means \pm SD, $n=36$, means followed by different letters in columns differ at $P<0.05$ according to Scott-Knott test.

\begin{tabular}{|c|c|c|c|c|c|c|c|c|}
\hline $\begin{array}{l}\text { Phosphorus } \\
\text { [mM] }\end{array}$ & $\begin{array}{l}\text { RGR } \\
\text { DKB390 }\end{array}$ & BRS1010 & $\begin{array}{l}\text { Leaves } \\
\text { DKB390 }\end{array}$ & BRS1010 & $\begin{array}{l}\text { Culm } \\
\text { DKB390 }\end{array}$ & BRS1010 & $\begin{array}{l}\text { Roots } \\
\text { DKB390 }\end{array}$ & BRS1010 \\
\hline 0.1 & $31.96 \pm 5.7^{\mathrm{a}}$ & $18.57 \pm 4.3^{\mathrm{a}}$ & $311.8 \pm 56^{\mathrm{a}}$ & $259.8 \pm 51^{\mathrm{a}}$ & $164.5 \pm 41^{\mathrm{a}}$ & $129.0 \pm 36^{\mathrm{a}}$ & $523.7 \pm 72^{\mathrm{a}}$ & $611.2 \pm 78^{\mathrm{a}}$ \\
\hline 0.4 & $43.24 \pm 6.6^{\mathrm{a}}$ & $21.59 \pm 4.6^{\mathrm{a}}$ & $300.6 \pm 55^{\mathrm{a}}$ & $263.7 \pm 44^{\mathrm{a}}$ & $165.9 \pm 41^{\mathrm{a}}$ & $134.1 \pm 37^{\mathrm{a}}$ & $533.5 \pm 73^{\mathrm{a}}$ & $602.1 \pm 78^{\mathrm{a}}$ \\
\hline 0.8 & $37.49 \pm 6.1^{\mathrm{a}}$ & $21.91 \pm 4.7^{\mathrm{a}}$ & $307.1 \pm 55^{\mathrm{a}}$ & $257.3 \pm 43^{\mathrm{a}}$ & $163.0 \pm 40^{\mathrm{a}}$ & $143.7 \pm 38^{\mathrm{a}}$ & $529.9 \pm 73^{\mathrm{a}}$ & $599.0 \pm 77^{\mathrm{a}}$ \\
\hline
\end{tabular}
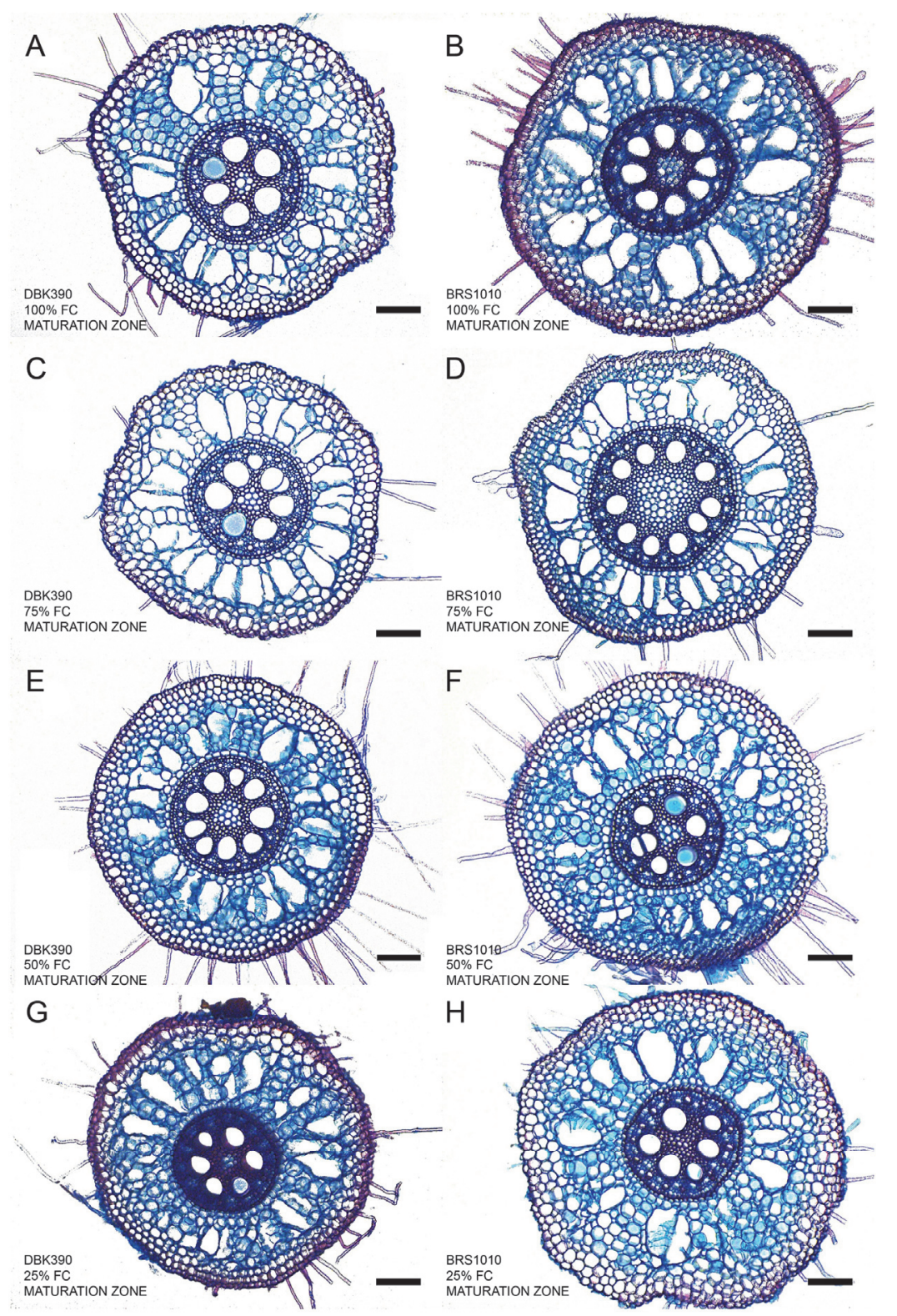

Fig. 3. Root sections in the maturation zone of two maize genotypes DKB390 (drought-tolerant; $A, C, E, G$ ) and BRS1010 (droughtsensitive; $B, D, F, H)$ under different water treatments. Field capacity $100 \%(A, B), 75 \%(C, D), 50 \%(E, F)$, and $25 \%(G, H)$. Bars $=100 \mu \mathrm{m}$. 
P concentration applied (Table 4 and Fig. 2), whereas in DKB390, P deficiency led to increased RCA development (Table 3 and Fig. 2). RCA development in the maturation zone showed different results as compared to the root-hair zone. The percentage of aerenchyma increased in both genotypes under $75 \% \mathrm{FC}$ as compared to $100 \%$ FC (Table 3 and Fig. 3). However, severe drought treatments (25 \% FC) slightly reduced RCA development in both the genotypes (Table 3 and Fig. 3). Percentage of RCA in DKB390 plants under $50 \%$ FC was higher than at $100 \%$ FC (Table 3 and Fig. 3). However, $\mathrm{P}$ had no effect on RCA development at the maturation zone for both the genotypes (Table 3). In addition, the exodermis and endodermis in the maturation zone showed thicker cell walls as compared to the root-hair zone.

Table 3. Phosphorus content $\left[\mathrm{mg}(\mathrm{P}) \mathrm{kg}^{-1}(\mathrm{~d} . \mathrm{m}\right.$.) $]$ and root aerenchyma proportion (RCA) $\left[\mu \mathrm{m}^{2}\right.$ (intercellular spaces) $\mu \mathrm{m}^{-2}$ (cortex)] in two maize genotypes DKB390 (drought-tolerant) and BRS1010 (drought-sensitive) under different water treatments and phosphorus concentrations. Means \pm SDs, $n=36$, means followed by different letters in columns differ at $P<0.05$ according to Scott-Knott test.

\begin{tabular}{|c|c|c|c|c|c|c|c|}
\hline \multirow[t]{2}{*}{ Treatment } & & \multicolumn{2}{|c|}{ Phosphorus content } & \multicolumn{2}{|c|}{ RCA in root-hair zone } & \multicolumn{2}{|c|}{ RCA in maturation zone } \\
\hline & & DKB390 & BRS1010 & DKB390 & BRS1010 & DKB390 & BRS1010 \\
\hline \multirow{4}{*}{$\begin{array}{l}\text { Field } \\
\text { capacity } \\
{[\%]}\end{array}$} & 100 & $0.73 \pm 0.2^{\mathrm{b}}$ & $0.91 \pm 0.2^{\mathrm{b}}$ & $19.74 \pm 1.0^{\mathrm{a}}$ & $26.33 \pm 0.9^{\mathrm{a}}$ & $13.39 \pm 0.7^{\mathrm{c}}$ & $19.05 \pm 0.4^{b}$ \\
\hline & 75 & $0.72 \pm 0.2^{\mathrm{b}}$ & $0.80 \pm 0.3^{\mathrm{c}}$ & $19.11 \pm 0.9^{\mathrm{a}}$ & $9.07 \pm 0.6^{\mathrm{b}}$ & $21.74 \pm 0.6^{\mathrm{a}}$ & $22.35 \pm 0.5^{\mathrm{a}}$ \\
\hline & 50 & $0.70 \pm 0.2^{\mathrm{b}}$ & $0.76 \pm 0.1^{\mathrm{c}}$ & $19.78 \pm 0.7^{\mathrm{a}}$ & $7.03 \pm 0.5^{\mathrm{b}}$ & $16.20 \pm 0.8^{\mathrm{b}}$ & $13.57 \pm 0.7^{\mathrm{c}}$ \\
\hline & 25 & $0.83 \pm 0.05^{\mathrm{a}}$ & $1.03 \pm 0.3^{\mathrm{a}}$ & $9.00 \pm 0.5^{\mathrm{b}}$ & $11.18 \pm 1.2^{b}$ & $10.59 \pm 0.6^{\mathrm{c}}$ & $11.88 \pm 0.4^{\mathrm{c}}$ \\
\hline \multirow{3}{*}{$\begin{array}{l}\text { Phosphorus } \\
{[\mathrm{mM}]}\end{array}$} & 0.1 & $0.55 \pm 0.16^{\mathrm{c}}$ & $0.53 \pm 0.09^{c}$ & $26.22 \pm 0.7^{\mathrm{a}}$ & $13.00 \pm 0.9^{\mathrm{a}}$ & $17.11 \pm 0.9^{\mathrm{a}}$ & $16.10 \pm 0.8^{\mathrm{c}}$ \\
\hline & 0.4 & $0.71 \pm 0.06^{\mathrm{b}}$ & $0.90 \pm 0.14^{\mathrm{b}}$ & $11.89 \pm 0.7^{\mathrm{b}}$ & $11.94 \pm 1.1^{\mathrm{a}}$ & $13.57 \pm 0.7^{\mathrm{a}}$ & $17.29 \pm 0.6^{\mathrm{c}}$ \\
\hline & 0.8 & $0.99 \pm 0.08^{\mathrm{a}}$ & $1.20 \pm 0.19^{\mathrm{a}}$ & $11.11 \pm 1.1^{\mathrm{b}}$ & $15.27 \pm 0.8^{\mathrm{a}}$ & $15.76 \pm 0.8^{\mathrm{a}}$ & $16.75 \pm 0.5^{\mathrm{c}}$ \\
\hline
\end{tabular}

\section{Discussion}

Although reduced aerenchyma development was observed in the root-hair zone, the maturation zone showed increased RCA in plants exposed to mild drought (Table 4 and Figs. 1, 2, and 3). Although this pattern is advantageous for root growth, it does not affect root water relations as older root parts are not involved much in water uptake (Lynch 2015). According to Steudle (2000), older root zones may show increased suberization in the endodermis and exodermis, thereby reducing water uptake. This variation in the water uptake capacity may be also related to the lower aquaporin development in more distal zones of the roots (Gambetta et al. 2013). The root maturation zones in both BRS1010 and DKB390 genotypes showed well-developed exodermis and endodermis preventing water uptake in this region (Table 1 Suppl.). The increased RCA development in this region thus reduced the metabolic costs but did not affect water uptake significantly.

In the root-hair zone, the pronounced reduction of the aerenchyma under $25 \%$ FC (observed in both genotypes) probably improved water and nutrient uptake. Increased $\mathrm{P}$ content under $25 \%$ FC supports our conclusion (Table 3). As aerenchyma may reduce radial water uptake by roots (Yang et al. 2012), a reduction of the aerenchyma development under severe drought stress may be important to maintain root hydraulic conductivity.

Aerenchyma seems to be very important to manage water stress tolerance in plants, however, its development depends on specific responses of maize genotypes. According to Pereira et al. (2008), BRS1010 has poor RCA development under waterlogged conditions, corroborating our results for the lower RCA formation in these plants. In addition, Souza et al. (2013) reported increased RCA development in the DKB390 genotype under drought stress. The differences in growth parameters of DKB390 (drought-tolerant) and BRS1010 (drought-sensitive) show their contrasting capacity to overcome water stress (Table 1). Although both genotypes showed reduced growth under severe drought, the growth parameters for DKB390 were remarkably higher. For instance, the relative growth rate was reduced by $85 \%$ in BRS1010, but only by $17 \%$ in DKB390, under severe drought. According to Coelho et al. (2006) RCA development in maize occurs only under suboptimal $\mathrm{P}$ content. Therefore, a higher capacity to upregulate RCA development in the drought-tolerant genotype DKB390 may be its important attribute to cope with water stress. Thus in maize, the aerenchyma formation under drought stress depends on genotype and root zone characteristics, and RCA may serve as a useful marker for breeding programs focusing on the development of drought-tolerant maize.

Poor phosphorus supply promoted RCA development only in the drought-tolerant genotype (Table 3 and Fig. 2). Also suboptimal concentrations of nitrogen, sulfur, and potassium promote RCA development (Bouranis et al. 2006, Postma and Lynch 2011), and RCA development upon low $\mathrm{P}$ concentration has been shown to be a common response in bean (Fan et al. 2003), maize (Coelho et al. 2006), and rice (Vejchasarn et al. 2016). Tropical soils, such as the Brazilian soils, are low in $\mathrm{P}$ content (Sousa et al. 2012) and $\mathrm{P}$ limitation can become 
severe owing to drought (He and Dijkstra 2014). Under natural conditions, combined limitation of water supply and $\mathrm{P}$ is likely to happen because drought reduces P uptake (He and Dijkstra 2014). Therefore, abiotic stress or a combination of stresses may stimulate RCA formation even though no direct interaction was found for these two factors on RCA development in maize roots. Drought tolerant genotypes might profit, with respect to survival and productivity, from RCA development under $\mathrm{P}$ deficiency and drought conditions.

Combined effects of $\mathrm{P}$ deficiency and drought on RCA formation are not well-known. Therefore, a combination of stresses may stimulate RCA formation

\section{Conclusion}

Both drought and phosphorus limitation influenced RCA formation, but no special effect of their combination was observed. RCA development varied along the root axis, and the response to drought was obviously genotypedependent. Reduction of root aerenchyma in the root-hair might improve water uptake whereas increased RCA formation in the maturation zone, as observed in the

\section{References}

Bouranis, D.L., Chorianopoulou, S.N., Kollias, C., Maniou, P., Protonotarios, V., Siyiannis, V.F., Hawkesford, M.J.: Dynamics of aerenchyma distribution in the cortex of sulfate-deprived adventitious roots of maize. - Ann. Bot. 97: 695-704, 2006.

Chimungu, J.G., Loades, K.W., Lynch, J.P.: Root anatomical phenes predict root penetration ability and biomechanical properties in maize (Zea mays). - J. exp. Bot. 66: 31513162,2015

Coelho, G.T.C., Souza, I.R.P., Carneiro, N.P., Schaffert, R.E., Brandão, R.A.L., Alves, V.M.C., Paiva, L.V., Carneiro, A.A.: [Aerenchyma formation in maize plants under phosphorus deficiency]. - Rev. Bras. Milho Sorgo 5: 443449 2006. [In Port.]

Fan, M., Zhu, J., Richards, C., Brown, K., Lynch, J.P.: Physiological roles for aerenchyma in phosphorus-stressed roots. - Func. Plant Biol. 30: 493-506, 2003.

Ferreira, D.F.: Sisvar: a computer statistical analysis system. Cien. Agrotec. 35: 1039-1042, 2011.

Gambetta, G.A., Fei, J., Rost, T.L., Knipfer, T., Matthews, M.A., Shackel, K.A., Walker, M.A., McElrone, A.J.: Water uptake along the length of grapevine fine roots: developmental anatomy, tissue-specific aquaporin expression, and pathways of water transport. - Plant Physiol. 163: 1254-1265, 2013.

He, M., Dijkstra, F.A.: Drought effect on plant nitrogen and phosphorus: a meta-analysis. - New Phytol. 204: 924-931, 2014.

Hoagland, D.R., Arnon, D.I.: The water-culture method for growing plants without soil. - California Agr. Expt. Sta. 347:1-39, 1950.

Hunt, R., Causton, D.R., Shipley, B., Askew, A.P.: A modern tool for classical plant growth analysis. - Ann. Bot. 90: 485488, 2002. even though no direct interaction was found for these two factors on RCA development in maize roots. The mechanism for drought-induced aerenchyma development remains unclear. Aerenchyma formation in maize is considered to be environmentally-induced: the RCA formation in maize under different stresses (hypoxia, mechanical impedance, and nutrient starvation) depends on ethylene and irradiance (Lenochová et al. 2009, Pires et al. 2015). Under hypoxia, the lower antioxidant system activity seems to be related to increased aerenchyma development (Pereira et al. 2010). Therefore, a higher RCA formation under mild to medium drought in the maturation zone may be related to ethylene signaling.

drought tolerant maize genotype, might reduce metabolic costs. Analysed genotypes also exhibited different responses to $\mathrm{P}$ supply, whereby the drought tolerant genotype showed increased aerenchyma formation at $\mathrm{P}$ limitation. Thus, genotype-specific responses have to be considered in future studies on RCA development and functions.

Jaramillo, R.E., Nord, E.A, Chimungu, J.G., Brown, K.M., Lynch, J.P.: Root cortical burden influences drought tolerance in maize. - Ann. Bot. 112: 429-437, 2013.

Johansen, D.A.: Plant Microtechnique. - Mc Graw-Hill, New York 1940.

Lenochová, Z., Soukup, A., Votrubová, O.: Aerenchyma formation in maize roots. - Biol. Plant. 53: 263-270, 2009.

Lynch, J.P.: Rhizoeconomics: the roots of shoot growth limitations. - Hortscience 42: 1107-1109, 2007.

Lynch, J.P.: Root phenes that reduce the metabolic costs of soil exploration: opportunities for $21^{\text {st }}$ century agriculture. Plant Cell Environ. 38: 1775-1784, 2015.

Magalhães, P.C., Lavinsky, A.O., Melo, H.F., Alves, J.C., Souza, T.C., Barbosa, A.P., Ribeiro, C.: Relationship between nitric oxide, enzymatic atioxidant system and ABA in maize under long-term drought. - Rev. Bras. Milho Sorgo 14: 155-166, 2015.

Pereira, F.J., Castro, E.M., Souza, T.C., Magalhães, P.C.: [Evolution of the root anatomy of 'Saracura' maize in successive selection cycles]. - Pesq. Agropec. Bras. 43: 1649-1656, 2008. [In Port.]

Pereira, F.J., Magalhães, P.C., Souza, T.C., Castro, E.M., Alves, J.D.: [Antioxidant system activity and aerenchyma formation in 'Saracura' maize roots]. - Pesq. Agropec. Bras. 45: 451-456, 2010. [In Port.]

Pires, M.F., Castro, E.M., Magalhães, P.C., Neta, I.C.S., Monteiro, A.G.D.P.: [Ethylene and hydrogen peroxide in the aerenchyma formation in maize tolerant to intermittent flooding]. - Pesq. Agropec. Bras. 50: 779-787, 2015. [In Port.]

Postma, J.A., Lynch, J.P.: Root cortical aerenchyma enhances the growth of maize on soils with suboptimal availability of nitrogen, phosphorus, and potassium. - Plant Physiol. 156: 1190-1201, 2011. 
Santos, K.R., Pereira, M.P., Ferreira, A.C.G., Rodrigues, L.C.A., Castro, E.M., Corrêa, F.F., Pereira, F.J.: Typha domingensis Pers. growth responses to leaf anatomy and photosynthesis as influenced by phosphorus. - Aquatic Bot. 122: 47-53, 2015.

Sarruge, J.R., Haag, H.P.: Análises químicas em plantas. [Chemical Analyses in Plants.] - ESALQ, Piracicaba 1974. [In Port.]

Sousa, S.M., Clark, R.T., Mendes, F.F., Oliveira, A.C., Vasconcelos, M.J.V., Parentoni, S.N., Kochian, L.V., Guimarães, C.T., Magalhães, J.V.: A role for root morphology and related candidate genes in $\mathrm{P}$ acquisition efficiency in maize. - Funct. Plant Biol. 39: 925-935, 2012.

Souza, T.C., Castro, E.M., Magalhães, P.C., Lino, L.O., Alves, E.T., Albuquerque, P.E.P.: Morphophysiology, morpho- anatomy, and grain yield under field conditions for two maize hybrids with contrasting response to drought stress. Acta Physiol. Plant. 35: 3201-3211, 2013.

Steudle, E.: Water uptake by roots: effects of water deficit. J. exp. Bot. 51: 1531-1542, 2000

Valdez, V.: Root hydraulics: the forgotten side of roots in drought adaptation. - Field Crops Res. 165: 15-24, 2014.

Vejchasarn, P., Lynch, J.P., Brown, K.M.: Genetic variability in phosphorus responses of rice root phenotypes. - Rice 9: 1-16, 2016.

Yang, X., Li, Y., Ren, B., Ding, L., Gao, C., Shen, Q., Guo, S.: Drought-induced root aerenchyma formation restricts water uptake in rice seedlings supplied with nitrate. - Plant Cell Physiol. 53: 495-504, 2012. 